\title{
HOXA1 Gene
}

National Cancer Institute

\section{Source}

National Cancer Institute. HOXA1 Gene. NCI Thesaurus. Code C115064.

This gene plays a role in embryonic pattern formation. 